\title{
Yerel Kalkınma Bağlamında Yerel Yönetim Birliklerinin Kuruluş Sürecinde Uygulanan Vesayet Denetimi ve Bir Model Önerisi
}

\author{
Burak Hamza ERYİĞİT
}

Öz

Dünyada ve Türkiye'de küreselleşme ekseninde gelişen yerelleşme olgusu yerel kalkınma kavramını daha fazla ön plana çıkartmıştır. Bu kapsamda Türkiye’de bir taraftan kamu yönetimini yeniden yapılandırmaya yönelik düzenlemeler ve buna bağlı yerel yönetim reformları uygulamaya sokulurken diğer bir taraftan bölgesel kalkınmayı bölgesel rekabet üzerinden hızlandırmayı amaçlayan kalkınma ajansları sisteme dâhil edilmiştir. Bahsi geçen dönemde yürürlüğe giren Mahalli İdare Birlikleri Kanunu yerel yönetim reformları içerisinde önemli bir yere sahiptir. Bu çalışmada yerel kalkınma açısından önemli bir niteliğe sahip olan yerel yönetim birliklerinin merkezi yönetim ile aralarında kurgulanmış olan vesayet ilişkisi göz önünde bulundurularak daha etkin bir şekilde örgütlenebilmelerinin sağlanabilmesi için bir model önerisi geliştirmek amaçlanmıştır. Türkiye'de yerel yönetim kuruluşları içerisinde yer alan il özel idareleri, belediyeler ve köylerin birlik kurabilmeleri için bakanlar kurulunun onayına ihtiyaç vardır. Bu durum yerel yönetim birliklerinin kurulmasını zorlaştırmış ve henüz kuruluş sürecinde uygulanan güçlü vesayet nedeniyle yerel hizmetlerin daha etkin, verimli ve sürekli verilmesinin önünde engeller oluşturmuştur. Güçlü vesayetin desantralize edilerek daha etkin bir denetim ilişkisinin kurgulanabilmesi için hazırlanan bu çalışmada; içerik analizi ve arşiv araştırması yöntemleri kullanılmıştır. Bu kapsamda bu çalışmada küresel düzlemde gelişen bölgesel kalkınma olgusunun önemli araçlarından birisi olan yerel yönetim birliklerinin önemi anlatılmış, ardından Türkiyede yerel yönetim birliklerinin tarihsel gelişimi ile uygulanan idari vesayet ve yerel yönetim birliklerinin durumu ele alınarak bahsi geçen kuruluşların kurumsallaşması sürecinde yeni bir vesayet modeli önerisi geliştirilmiştir. Yerel yönetim birliklerinin kuruluş sürecinde mevcut model dâhilinde vesayet ilişkisinin desantralize edilmesi durumunda; bu kuruluşların daha etkin şekilde kurulmasının ve hizmet vermesinin sağlanacağı sonucuna varılmıştır.

Anahtar kelimeler: Yerel Yönetim Birlikleri, Yerel Kalkınma, Vesayet, Desantralizasyon.

* Bu çalışma 3-6 Mart 2016 Tarihleri Arasında YEKAF tarafından Antalyada düzenlenen Uluslararası Yerel Kalkınma ve Finansman Kongresi’nde sunulan bildirinin genişletilerek ele alınmış halidir.

** Yrd. Doç. Dr., Marmara Üniversitesi Siyasal Bilgiler Fakültesi Yerel Yönetimler Bölümü.

E-posta: burakhamzaster@gmail.com 


\title{
Tutelage Audit Conducted During the Formation Process of Local Government Unions within the Context of Local Development and a Model Proposal
}

\begin{abstract}
The issue of localization that is developed within the framework of globalization throughout the world and Turkey has brought forward the concept of local development even further. Within this scope, regulations and related local government reforms regarding the reconstruction of public administration in Turkey have been implemented on one hand while development agencies that intend to facilitate regional development through regional competition have been integrated to the system. The Law on Local Government Union which was enacted during the aforementioned period has a crucial role among local government reforms. This study intends to propose a model for the purpose of initiating a more efficient organization of local government unions, which are significant in terms of regional development, and central government by taking the tutelage relations built between them into consideration. In Turkey, the provincial private administrations, municipalities and villages that remain within local government organizations require approval from the council of ministers in order to form a union. This circumstance has complicated the formation of local government unions and has created obstacles while attempts are made to provide efficient, productive and continuous local services due to the powerful tutelage applied during the formation process. Attempting to form a more efficient audit relationship by decentralizing the powerful tutelage, this study has applied content analysis and archival research methods. In this respect, it explains the importance of local government unions that are one of the crucial devices of regional development in global terms while the subsequent chapters deal with the historical development of local government unions in Turkey, the administrative tutelage implemented as well as the state of local government unions, and the final chapter proposes a new tutelage model during the institutionalization process of the aforementioned organizations. It has been concluded that if the decentralization of the tutelage relations within the scope of the current model during the formation process of local government unions takes place, the formation of these organizations shall be more efficient with more effective services.
\end{abstract}

Keywords: Local Government Unions, Local Development, Tutelage, Decentralization

\section{Giriş}

Küreselleşme ile birlikte gelişen yerelleşme olgusu, ulus devletlerin bir takım güç, yetki ve sorumluluklarını daha üst ve alt ölçekli organizasyonlarla paylaşmasını beraberinde getirmiştir. İktisadi açıdan ulus devlete yüklenen büyüme ve kalkınma konularındaki sorumluluk, bu paylaşım ile birlikte yerel ve bölgesel organizasyonları örgütleme ve bunlar ile işbirliğini beraberinde getirmiştir. Bu kapsamda yerel düzlemde büyüme ve kalkınmanın sağlanmasına dönük ön plana çıkan aktörlerden birisi de yerel yönetim birlikleri olmuştur.

Ülkelerin kendi siyasi, hukuki, yönetsel, tarihi ve toplumsal yapılarına göre yerel yönetim 
birliklerinin örgütlenme biçimi ile yetki ve sorumlulukları birbirinden farklılıklar göstermiştir. Türkiye; siyasi ve tarihsel perspektifte yaşamış olduğu deneyimler neticesinde üniter devlet modelini benimsemiş ve yönetsel düzlemde yetki ve kaynakları olabildiğince merkezileştirmiş̧tir. Son dönemde dünyada yaşanan gelişmelere paralel ortaya çıkan bölgeselleşme ve yerelleşme olgusu, Türkiye’yi de etkilemiş ve yerel yönetim birliklerini de içine alan birçok reform hayata geçirilmiştir.

$\mathrm{Bu}$ çalışmada küreselleşme ekseninde gelişen yerel kalkınma olgusu, Türkiye'deki yerel yönetim birliklerinin örgütlenme süreçleri üzerinden değerlendirmeye tabi tutularak, bahsi geçen organizasyonların yerel kalkınma hususunda daha etkin bir rol üstlenebilmesi için kuruluş sürecinde işletilen vesayet denetiminin desantralizasyonuna yönelik bir model önerisi geliştirilmeye çalışılmıştır.

\section{Küreselleşme Ekseninde Yerel Kalkınma ve Yerel Yönetim Birlikleri}

Küreselleşmenin getirdiği olumsuzluklarla birlikte, geleneksel yukarıdan aşağıya kalkınma politikalarının başarısızlı̆ııın ortaya çıkması, devam eden kalkınma yaklaşımlarının sorgulanmasına neden olmuştur. Bunun sonucu olarak, yerel ekonomik kalkınma yaklaşımı çerçevesinde bir dizi politika ve strateji üretilmeye başlanmıştır (Çetin, 2007:153). Ayrıca küreselleşmeye paralel olarak gelişen yerelleşme olgusu; ulus devletlerin ellerinde bulunan birçok görev, yetki ve sorumluluğun yerel yönetimlere devredilmesini beraberinde getirmiştir. $\mathrm{Bu}$ durum ulus devletlerin birbirleri arasındaki iktisadi, siyasi, yönetsel, kültürel, sosyolojik ve teknolojik yönden beliren rekabetin artık bölgeler üzerinden yürümesinin bir sonucudur. Bu kapsamda bölgeler üzerinden yürüyen rekabette dikkatler ulus devlet sinırları içerisinde bölgeler arası eşitlikten ziyade, küresel ölçekte bölgeler arası rekabete evrilmiştir. Rekabette kendi sınırları içerisinde yer alan bölgeleri daha avantajlı hale getirmek isteyen ülkeler, bir yandan dışsal büyümeye ve kalkınmaya dönük bir takım yeni politika ve stratejiler geliştirirlerken, diğer taraftan içsel büyüme ve kalkınma dinamiklerini harekete geçirecek önlemler almayı ihmal etmemişlerdir.

Bölgesel kalkınmanın sağlanmasında önemli araçlardan birisi de kurumsal kapasitenin geliştirilmesidir. Farklı alan ya da amaca hizmet etmek için güçlü organizasyonlar kuran ve bu organizasyonların amaçlarını gerçekleştirebilmesine yönelik birlikte hareket edebilme potansiyelini güçlü bir biçimde harekete geçiren bölgeler, diğer bölgelere göre daha avantajlı konuma gelmektedir.

Yerel kaynakların etkin ve rasyonel bir biçimde kullanılarak bölgesel kalkınmanın hızlandırılması, o bölgedeki yerel kurumların bölge yönetimindeki koordinasyonuna bağlıdır. Koordinasyonun gerçekleşmesinde en önemli görev yerel halka karşı sorumluluğu fazla olan yerel yönetimlere düşmektedir (Bilgin, 2002:328).

Yerel yönetim birliklerinin ortaya çıkışında toplum kalkınması düşüncesinin önemli etkisi 
olmuştur. Türkiyede toplum kalkınması kavramının ilk kez ele alınıp tartışıldığı dönem 1960’lı yllardır. (www.die.gov.tr, 24.07.2004’ten aktaran, Kara ve Görün, 2008:418).

Yerel yönetim birimlerinin bir araya gelmeleri, yeryüzündeki deneyimler gözden geçirildiğinde, ya birleşmeler (amalgamation) biçiminde, ya da işbirliği yapma (cooperation) biçiminde olmaktadır. Birleştirmenin başlıca nedenleri, yerel birimlerin, görevlerini etkin olarak yerine getiremeyecek ölçüde küçük olmaları, öz gelirlerinin ve devletten aldıkları payların yetersiz bulunması, yeterli düzeyde öğrenim görmüş ve deneyimi bulunan görevlilere sahip olmamaları ve son olarak da, kamu hizmetlerinin giderek karmaşıklaşmasının yerel birimlerin türlü organlarında görev almış kimselerin üst düzeydeki ilişkileri kavramakta güçlük çekmeleridir. Bu yüzdendir ki, kimi batılı ülkelerdeki yerel birimler, birleşme yoluyla büyüme yolunu seçmişlerdir. "Ya birleşirsin, ya yıkılıp gidersin (to merge or to perish) sözü bu amaçla kullanılmıştır (Keleş, 2012:441).

Yerel yönetim birlikleri şu şekilde de tanımlanabilir: "Ortak bazı yerel kamusal ve hizmetlerin daha etkin, verimli, sürekli ve kaliteli bir şekilde sunulması için ilgili kanununda gösterilen şekilde bir araya gelen ve yine karar ve yürütme organlarının bahsi geçen yerel yönetimlerin tercihleri üzerinden oluşturulduğu kamu tüzel kişileridir.

\section{Türkiye'de Yerel Yönetim Birliklerinin Tarihsel Gelişimi}

Türkiyede, yakın dönemde yoğunlaşan yeniden yapılanma çalışmaları küresel gelişmeler dikkate alınarak yürütülmüştür. Gelişmiş modeller örnek alınarak, bu modellerdeki kavramlar, kurumlar ve ilkeler yeniden yapılanmayla ilgili yasalara eklemlenmiştir. Tarihsel gelime sürecine bakıldığında, 1839 Tanzimat Fermanıyla birlikte hem merkezi yönetimde hem de yerel yönetimde kararlı bir biçimde Batılı tipolojilere uygun bir yeniden yapılanma çabasının başladı̆̆ı söylenebilir. Reformların sürekliliği konusunda önemli sıkıntılar yaşansa da, o dönemden günümüze yönetim anlayışında, yurttaş-yönetim ilişkilerinde ve kamu hizmetinin sunumu konusunda önemli mesafeler alınmıştır. Cumhuriyet döneminde özellikle 1980'li yıllarla birlikte çağdaş dünyadaki gelişmeler daha yakından izlenebilmiş ve Türkiye’nin bu çizgiyi yakalaması konusunda önemli adımlar atılmıştır (Çukurçayır, 2013:318-319).

Cumhuriyet öncesi dönemde, yerel yönetim birliklerine benzeyen vakıflar, ahilik ve lonca teşkilatı ve divanlar gibi bazı birimler ortaya çıkmış ise de, yerel yönetim birliklerinin ilk örnekleri Cumhuriyetin kurulması ile görülmeye başlanmıştır (Köseoğlu, 2010:86). Türk Yerel Yönetim Sistemi açısından birliklere ilk güçlü atfın 1913 yllında çıkartılan İdare-i Umumiye-i Vilayat Kanun-i Muvakkati’nin 145 ve 146. maddelerinde rastlamak mümkündür. Cumhuriyet' in kurulduğu dönemde nüfusun büyük bir oranının köylerde yaşaması nedeniyle köyün yönetsel boyutunu düzenlemeye dönük 442 Sayılı Köy Kanunu yürürlüğe konulmuş ve bu kanunun 47 . maddesinde köylerin kuracakları birliklere atıf yapılmıştır. 1930 yılında yürürlüğe giren 1580 sayılı Belediye Kanunu 133 ve 148. maddelerinde belde, köy ve il yerel yönetimlerinin kendi aralarında kuracakları birlikler ile ilgili düzenlemelere yer vermiştir. 
$\mathrm{Bu}$ dönemde birliklerin sayısı çok sınırlıdır. Daha önce anayasal düzeyde dayanağı olmayan birliklere, ilk kez 1961 Anayasa’sında yer verilerek, birlik sayısının artması hedeflenmiştir. 1982 Anayasası sonrasında birlik sayısında yoğun bir artışolmuştur (Köseoğlu, 2010:86). 1982 Anayasası birlikler ile ilgili 127. maddenin son fikrasında "Mahallî idarelerin belirli kamu hizmetlerinin görülmesi amacı ile, kendi aralarında Bakanlar Kurulunun izni ile birlik kurmaları, görevleri, yetkileri, maliye ve kolluk işleri ve merkezî idare ile karşılıklı bağ ve ilgileri kanunla düzenlenir”. Söz konusu düzenleme ile yerel yönetimlerin kendi aralarında kuracakları birliklerin izni 1961 Anayasası'ndaki düzenlemeden farklı olarak bakanlar kurulunun takdirine bırakılmıştır.

Türkiye'de 2000'li yılların başından itibaren kamu yönetimi ve dolayısı ile yerel yönetimlere yönelik güçlü bir reform süreci işletilmiştir. Bahsi geçen reformların yapılış amaçlarından birisinin dünyada küreselleşme ile paralel gelişen bölgeselleşme olgusunu destekleyen desantralizasyon sürecini güçlendirmek olduğu söylenebilir. Bu kapsamda reformlarda benimsenen genel yetki ve yetki ilkeleri bağlamında birçok kamusal mal ve hizmetin yerel yönetimler tarafından sunulmasının önü açılmıştır. Yapılan önemli reformlardan birisi de hiç şüphesiz 5355 sayılı Mahalli İdare Birlikleri Kanunu olmuştur. Söz konusu kanun ile 1913 tarihli İdare-i Umumiye-i Vilayat Kanun-i Muvakkati, 442 sayılı Köy Kanunu, 1580 sayılı Belediye Kanunu ile ayrı ayrı ele alınmış olan yerel yönetim birliklerinin tek çatı altında değerlendirildiği yeni bir döneme girilmiştir. Mahalli İdare Birlikleri Kanunu’nda yerel yönetim birliği, "birden fazla mahalli idarenin, yürütmekle görevli oldukları hizmetlerden bazılarını birlikte görmek üzere kendi aralarında kurdukları kamu tüzel kişiliğini ifade eder” (Md:3); şeklinde tanımlanmıştır.

$\mathrm{Bu}$ işbirliklerinin en yaygın olanı "Köylere Hizmet Götürme Birlikleri” olarak bilinen örgütlenmelerdir. Köylere hizmet götürme birlikleri dışında da değişik mahalli idare birlikleri kurulabilmektedir. Bu çerçevede 5355 sayılı Mahalli İdare Birlikleri Kanunu, il özel idareleri, belediyeler ve köyleri de kapsamak üzere yerel yönetimler arası değişik işbirliği türleri için tüzel kişilik anlamında yasal bir altyapı oluşturmuştur. Bir bütün olarak Mahalli İdare Birlikleri kuruluş amaçlarına göre aşağıdaki şekilde sınıflandırılabilmektedir (TBB, 2010:16-17, Eryiğit, 2015:36):

1. Ülke düzeyinde kurulan birlikler (Türkiye Belediyeler Birliği ve Vilayetler Hizmet Birliği)

2. Üye sayısı 100 'den fazla olan birlikler (Genellikle birden çok ili kapsayan, bazen belli bir coğrafi bölgedeki mahalli idarelerin oluşturduğu mahalli idare birlikleri: Marmara Belediyeler Birliği)

3. Turizm altyapı hizmet birlikleri (5355/ek madde l’e göre kültür ve turizmi koruma ve gelişim bölgeleri ile turizm merkezlerinde kurulması zorunludur)

4. Sulama birlikleri (Tarım arazilerinin sulanmasını yürütmek için kurulan birlikler)

5. Köylere hizmet götürme birlikleri

6. Bazı önemli projelerin yürütülmesi açısından kurulan birliğe katılmanın (yol, su, atık su, katı atık ve benzeri altyapı hizmetleri ile çevre ve ekolojik dengenin korunmasını 
gerektiren projeler gibi) zorunlu hale getirilmesi; kamu kurumlarının köye yönelik hizmetlerini Köylere Hizmet Götürme Birlikleri aracılığı ile gerçekleştirebilmeleri)

7. Diğer birlikler (Yukarıda sayılanların dışında birden çok mahalli idarenin ortak amaçlarını gerçekleştirmek üzere kurdukları birlikler). Buna karşılık belediyelerin birbirlerine yaptıkları karşılıklı yardımlar (park yapma, araç gönderme vb.) gibi daha küçük çaptaki işbirlikleri ise 5355 sayılı kanunda açıkça tanımlanmamakta; ancak 5393 sayılı kanunun belediyelerin diğer kuruluşlar ile ilişkilerini düzenleyen 75'inci maddesi bu tür faaliyetlere de imkân vermektedir.

Tablo I. 6360 Sayılı Kanun Öncesi ve Sonrası Türleri İtibari ile Yerel Yönetim Birliklerinin Sayıları

\begin{tabular}{llcc}
\hline \multicolumn{1}{c}{ S.No } & \multicolumn{1}{c}{ Türü } & Eski Durum & Yeni Durum \\
\hline 1 & Ülke Düzeyinde Birlikler & 2 & 2 \\
2 & Belediye Hizmet Birliği & 68 & 56 \\
3 & Özel İdare-Belediye Hizmet Birliği & 14 & 11 \\
4 & Kalkınma Birliği & 13 & 11 \\
5 & Çevre Altyapı Hizmet Birliği & 135 & 98 \\
6 & Turizm Birliği & 71 & 53 \\
7 & İçmesuyu Birliği & 177 & 93 \\
8 & Köylere Hizmet Götürme Birliği & 911 & 444 \\
9 & Diğer & 20 & 15 \\
\multirow{2}{*}{ Toplam } & & 1.411 & 783 \\
\hline
\end{tabular}

Kaynak: Mahalli İdareler Genel Müdürlüğü’nün 2015 verilerine dayanılarak hazırlanmıştır, http://www. migm.gov.tr/kurumlar/migm.gov.tr/YAYINLAR/FAAL\%C4\%B0YET\%20RAPORARI/2014_Faaliyet_ Raporu.PDF) [Erişim Tarihi: 07.02.2016].

\section{Türkiye'de Uygulanan İdari Vesayet ve Yerel Yönetim Birlikleri'nin Durumu}

Yönetimde merkeziyetçi yapılardan uzaklaşma ve yerelleşme eğilimlerinin belirginleştiği günümüzde, demokrasinin güçlendirilmesi ve yaygınlaştırılması bağlamında yerel özerklikler sürekli gündemde tutulmakta ve yerel yönetimler yalnızca bir hizmet kuruluşu olarak değil, aynı zamanda demokratik siyasi kurumlar olarak yeni işlevler üstlenmektedirler. Merkezi yönetim ile yerel yönetimler arasındaki ilişkilerin bu gelişmeler ışı̆̆ında yeniden ele alınması ve yerel yönetimlere daha fazla görev, yetki ve kaynak aktarımında bulunulması, yönetsel reform hareketlerinin esas esprisini oluşturmaktadır (Parlak, 2014:8). Türkiye’nin de taraf olduğu Avrupa Yerel Yönetimler Özerklik Şartı’nda yerel özerklik şu şekilde ifade edilmiştir (Madde:3): 
“Özerk yerel yönetim kavramı yerel makamların, kanunlarla belirlenen sinırlar çerçevesinde, kamu işlerinin önemli bir bölümünü kendi sorumlulukları altında ve yerel nüfusun çıkarları doğrultusunda düzenleme ve yönetme hakkı ve imkânı anlamını taşır. Bu hak, doğrudan, eşit ve genel oya dayanan gizli seçim sistemine göre serbestçe seçilmiş üyelerden oluşan ve kendilerine karşı sorumlu yürütme organlarına sahip olabilen meclisler veya kurul toplantıları tarafından kullanılacaktır. Bu hüküm, mevzuatın olanak verdiği durumlarda, vatandaşlardan oluşan meclislere, referandumlara veya vatandaşların doğrudan katılımına olanak veren öteki yöntemlere başvurulabilmesini hiçbir şekilde etkilemeyecektir".

Avrupa Birliği ülkelerindeki örneklerinde belediye birlikleri kent hayatında önemli kamusal hizmetleri yerine getirmektedirler. Bu faaliyetlerin yerine getirilmesinde merkezin hükümetlerin yasal ve finansal destekleri de çok önemli rol oynamaktadır. AB ülkelerindeki belediye birliklerinin kuruluşunda belirli modellerin dayatılmaması, denetimli-hukuksal serbestlik, sorumluluk ölçüsünde sağlanan maddi teşvikler, yerel nitelikli vergilerden birliklere pay ayrılması gibi unsurlar bu kurumların başarısındaki en önemli unsurlar olarak öne çıkmaktadır. Tabi ülkelerin merkezi yönetimlerinin, yerel yönetimler üzerinde uyguladığı idari vesayetin derecesi de yerel yönetimlerin ve yerel yönetim birliklerinin de özerkliğini etkilemektedir. Yerel özerkliğin yüksek olduğu ülkelerde yerel yönetim birlikleri de daha etkin ve verimli kamusal hizmetler ortaya çıarmaktadırlar (Zengin, 2011:104).

Türkiye'de yerel özerklik ile idari vesayet arasındaki ilişkinin hukuki ve idari anlamda temelini ve derinliğini ifade eden düzenlemeler 1982 Anayasası’nın 123. ve 127. Maddesi’nde ayrı ayrı ele alınmıştır. Anayasanın 123. maddesinde "idare, kuruluş ve görevleriyle bir bütündür ve kanunla düzenlenir"; ibaresine yer verilmiş ve 127. maddesinde; "merkezi idare, mahalli idareler üzerinde, mahalli hizmetlerin idarenin bütünlüğü ilkesine uygun şekilde yürütülmesi, kamu görevlerinde birliğin sağlanması, toplum yararının korunması ve mahalli ihtiyaçların gereği gibi karşılanması amacıyla, kanunda belirtilen esas ve usuller dairesinde idari vesayet yetkisine sahiptir". Söz konusu düzenlemelerden anlaşılacağı gibi merkezi yönetim ile yerel yönetimler arasında eşgüdümün sağlanması, görev, yetki ve kaynakların kullanımında bütünlüğün temin edilmesi için merkezi yönetim ve taşra teşkilatının yerel yönetim kuruluşları üzerinde uyguladığı denetime vesayet denetimi denir.

İdari vesayet, yerinden yönetim kuruluşlarının işlem ve eylemleri üzerinde olabileceği gibi, bu idarelerin organ ve görevlileri üzerinde de kullanılabilir. İdari vesayetin önemli bir bölümü, yerinden yönetimlerin işlemleri üzerinde kullanılır. İşlemler üzerindeki denetimler genellikle hukuka uygunluk ve kimi kez de yerindelik açısından olur. Merkezi yönetim, yerinden yönetimin işlemlerini onaylama, bozma ya da uygulanmasını geciktirme yetkilerine sahiptir (Boztepe, 2014:97).

Türkiye'de bu kapsamda yerel yönetimler üzerinde uygulanan vesayet yetkisi her ne kadar son dönemde yapılan yerel yönetim reformları ile takdir yetkisinden hukuka uygunluk denetimine evrilmeye çalışılsa da, takdir yetkisinin fazlası ile öncelendiği uygulamalar gözlerden kaçmamaktadır. Bu durum idari vesayetin merkeziyetçiliği perçinleyen yankıları şeklinde yerel özerklik alanını fazlası ile daraltmaktadır. 
Toplum yararına uygunluğun ölçüsünü, herkesçe kabul edilebilir objektif ölçüte bağlamak zordur. Siyasi partiler, toplum yararını kendilerine göre değişik yorumlamakta ve bu nedenle de farklı programlara sahip olmaktadırlar. Siyaset, toplum yararına yönelik faaliyet olmasına rağmen, farklı siyasi programların ortaya çıkması, "toplum yararı" kavramının düşünce ve ideolojiye göre değişen bir fenomen olmasından kaynaklanmaktadır. "Mahalli ihtiyaçların gereği gibi karşılanması "ilkesi de, tıpkı "toplum yararı" gibi belirsiz ve yoruma açık bir kavramdır. $\mathrm{Bu}$ tür objektif olmayan ve hukuki bir ölçüte bağlanamayan denetim ilkeleri, keyfi tasarruflara her zaman neden olabilir. $\mathrm{Bu}$ da siyasi mücadele ve sürtüşmeye malzeme hazırlar. Bu nedenle idari vesayet denetiminin, hukukilik ilkesiyle sınırlandırılması gerekir (Eryılmaz, 2014:224).

2004 yılından beri yapılan yerel yönetim reformları bir taraftan bu kuruluşların daha demokratik bir yapıya evrilmesini ve böylece güçlenmesini amaçlarken diğer taraftan ölçek ekonomileri göz önünde bulundurularak bu kuruluşların zorunlu bir biçimde birleştirilmesini ya da kapatılmasını beraberinde getirmiştir.

Bir hizmetin üretim ölçeği genişledikçe, üretimde artış oranının maliyetteki artış oranından daha yüksek olması sonucunu doğuran bir etki yapması durumuna ölçek yaklaşımı denilebilir. Küçük ölçekli yönetim birimlerinin daha demokratik buna karşılık büyük ölçekli birimlerin ise, ekonomik yönden daha verimli ve etkin olduğu konusu tartışılmakla beraber, uygulamada büyük ölçekli birimlerin daha etkin olduğu yönündeki eğilimin galip çıktığını ve yapılanmanın buna göre gerçekleştiği söylenebilir (Eryılmaz, 2014:177). 2008 yılında kabul edilen 5747 sayılı kanun ${ }^{1}$ ile 2012 yılında kabul edilen 6360 sayılı kanun²'un lafzı ve ruhuna bakıldığında ölçek üzerinden yeni bir yapılanmaya gidilmeye çalışıldı̆̆ı söylenebilir.

Yerel yönetimlerin komün esaslı vasıfları ile demokratik değerlerin gelişmesini sağlayan okul olma yanlarını koruyarak ölçek yaklaşımı üzerinden yerel kamusal mal ve hizmetleri etkin, verimli, kaliteli, sürekli bir şekilde sunabilmelerinin en kolay yolu, bu kuruluşların kendi aralarında birlik kurabilmelerini kolaylaştırmaktır.

2005 yllında 5355 sayılı Mahalli İdare Birlikleri Kanunu ile yerel yönetimlerin birbirlerine kenetlenerek yerel halkın menfaatlerini daha güçlü savunabilecekleri ve yerel kalkınmayı daha güçlü sağlayabilecekleri bir yeni hukuki altlık oluşturulmuş olsa da; 1982 Anayasası̉nın 127. maddesinde yer alan "Mahallî idarelerin belirli kamu hizmetlerinin görülmesi amacı ile kendi aralarında Bakanlar Kurulunun izni ile birlik kurmaları, görevleri, yetkileri, maliye ve kolluk işleri ve merkezî idare ile karşılıklı bağ ve ilgileri kanunla düzenlenir”; ibaresi nedeniyle, vesayet ilişkisi açısından hukuka uygunluktan ziyade takdir yetkisinin ön plana çıkartıldığı bir çerçeve oluşturulmuştur. 5355 sayılı Mahalli İdare Birlikleri Kanunu da "Birlik, birlik tüzüğünün kesinleşmesinden sonra Bakanlar Kurulunun izni ile kurulur ve tüzel kişilik kazanır”; denilmek

15747 Sayılı Büyükşehir Belediyesi Sınırları İçerisinde İlçe Kurulması ve Bazı Kanunlarda Değişiklik Yapılması Hakkında Kanun.

26360 sayılı On Üç İlde Büyükșehir Belediyesi ve Yirmi Altı İlçe Kurulması ile Bazı Kanun ve Kanun Hükmünde Kararnamelerde Değişiklik Yapılmasına Dair Kanun. 
suretiyle 1982 Anayasası'nın ilgili düzenlemesine uygun takdir yetkisini önceleyen güçlü vesayet uygulamasını pekiştirmiştir.

1982 Anayasası ve 5355 sayılı Mahalli İdare Birlikleri Kanunu’nda; yerel yönetimlerin aralarında birlik kurmalarının zorlaştırılması, Türkiye’de yerel kalkınmanın en önemli lokomotifi olabilecek bu kuruluşların iş ve güç birliği yapmalarını zorlaştırmaktadır. Bu zorluğu aşabilmek için yerel yönetimler, her ne kadar geçici protokoller ve alternatif hizmet üretme yöntemlerine müracaat etseler de, bunlardan hiç birisi birlik şeklinde örgütlenmeleri gibi etki oluşturmamaktadır.

Bu nedenle yerelde demokratik değerler ile ölçek ekonomileri üzerinden yerel kalkınmanın bir bütün halinde işletilebildiği bir açlıma ihtiyaç vardır. Burada ilk olarak yerel yönetim birliklerinin etkin şekilde kurumsallaşabilmesinin önünü açacak hukuki, siyasi, idari ve toplumsal önlemlerin hayata geçirilmesi gerekmektedir. Bu gerekliliğin istenilen karşılığı bulabilmesi için yönetsel açıdan bu kuruluşların kurumsallaşması sürecinde uygulanan vesayeti daha etkin şekilde işletilmesini saylayacak bir modele ihtiyaç vardır. Bu model önerisi aşağıda ele alınmıştır.

\section{Yerel Yönetim Birlikleri’nin Kurumsallaşma Sürecinde Yeni Bir Vesayet Modeli Önerisi}

Yerel yönetim birliklerinin kurulması sürecinde 1982 Anayasası ve Mahalli İdare Birlikleri Kanunu'nda öngörülen idari vesayet yaklaşımı hukuka uygunluktan ziyade takdir yetkisini ön plana çıkartan ve yerel yönetimlerin birlikte hareket etme gayretlerini zorlaştıran bir derinliğe sahiptir. Bu kapsamda Avrupa Yerel Yönetimler Özerklik Şartı’nda vurgulanan ve son dönemde kamu hizmetlerinin sunumunda ön plana çıkan "subsidiarite ilkesi”nin (md:4), yerel yönetim birliklerinin kuruluş sürecinde işletilen vesayet sürecinde de öncelenmesi gerekmektedir.

1982 Anayasası’nın 123. maddesine göre; "kamu tüzel kişiliği, ancak kanunla veya kanunun açıkça verdiği yetkiye dayanılarak kurulur”. Bu madde ile Türkiyede bir kamu tüzel kişiliği vücuda getirmek için ya TBMM tarafından bir kanun yapılması, ya da kanunda bu kamu tüzel kişiliğinin kurulmasını takdir edecek bir merciinin belirtilmesi istenmiştir. Belli başlı kamu tüzel kişiliklerinin oluşturulmasında kanun şartı getirilmediği durumlarda bu yetki bakanlar kuruluna tevdi edilmiştir. Bu nedenle bir kamu tüzel kişisi olan yerel yönetim birliklerinin kurulmasına karar verilmesi konusunda yetkili merci, "bakanlar kurulu” olarak ifade edilmiştir.

Kırsal, kentsel ve bölgesel alanlardaki kalkınmanın sağlanmasında çok önemli bir yeri olan yerel yönetim kuruluşlarının; geleceğe dönük stratejilerini ve planlarını oluşturabilmeleri ve yerel kamusal mal ve hizmetleri etkili şekilde sunabilmeleri için aralarında birlik kurmalarında Bakanlar Kurulu’nun izninin aranması; bu yapıların bir kısmının henüz daha vücuda gelmeden ölü doğmasının önemli gerekçelerinden birini oluşturmaktadır. Bugün, kırsal alanda herhangi bir kamusal faydayı üretmek için birkaç köyün bir araya gelip birlik kurmayı istemesi bile Bakanlar Kurulu'nun onayını gerekmektedir. Bu durum, ilçe, il ve bölge düzeyinde kurulması düşünülen birlikler için farklı değildir. 
Burada birliklerin kurulması sürecinde Bakanlar Kurulu’nun izninin aranması iki büyük sorunu beraberinde getirmektedir. Birinci sorun Bakanlar Kurulu’nun izin verip vermeme konusunda göstereceği tavır ile alakalı iken, diğer sorun ise birlik kurulması ile ilgili tüm verilerin Bakanlar Kurulu'nun gündemine girmesi için işleyen bürokratik süreci kapsamaktadır. Bakanlar Kurulu'nun gündemine birlik ile ilgili sürecin dâhil edilmesi ve gerekli iznin alınması birçok bürokratik işlemi ve büyük zaman kayıplarını beraberinde getirmektedir. Ayrıca kurulmak istenen birliklerin ihtiyaca cevap verip veremeyeceği konusunda Bakanlar Kurulu’nun tam ve eksiksiz bilgiyle hareket etmesi de pek mümkün gözükmemektedir.

Bu nedenle hem kırsal, hem kentsel ve hem de bölgesel anlamda yerel kalkınmanın ve demokratik gelişimin güçlü bir şekilde sağlanabilmesi için farklı alanlarda kurulması planlanan yerel yönetim birlikleri ile ilgili yine farklı bir vesayet sürecinin işletilmesi gerekmektedir. Söz konusu işletilmesi önerilen model aşağıdaki tabloda ayrıntılı olarak ele alınmıştır.

Tablo 2. Yerel Yönetim Birlikleri'nin Kuruluşunda Önerilen Yeni Vesayet Modeli

Birliğin Şekli

Köy Birlikleri

Köylere Hizmet Getirme Birlikleri

Bir İlçeyi Kapsayan Su Getirme Birliği

Birden Fazla İlçeyi Kapsayan Su Getirme Birliği

Farklı İlleri Kapsayan Kalkınma Birliği

Aynı İl İçindeki Turizm Altyapı Hizmet Birliği

Farklı İlleri Kapsayan Turizm Altyapı Hizmet Birliği

Aynı İl İçindeki Belediyeler Birliği

Farklı İllerdeki İl, İlçe ve Belde Belediyeler Birliği

İl Özel İdare, Belediye ve Köylerin

Kendi Aralarında Kuracakları Yerel Yönetim Birliği

Bölgesel Düzeyde Belediye Birliği

Ülke Düzeyinde Belediye Birliği

Bölge Düzeyinde Özel İdare Birliği

Ülke Düzeyinde Özel İdare Birliği

\section{Kuruluş İzni}

İlçe Kaymakamı

İlin Valisi

İlçe Kaymakamı

İlin Valisi

İllerin Valileri

İlin Valisi

İllerin Valileri

İlin Valisi

İllerin Valileri

İlin Valisi

Bakanlar Kurulu

Bakanlar Kurulu

Bakanlar Kurulu

Bakanlar Kurulu 
Vesayet yetkisinin "subsidiarite ilkesi”nden esinlenerek birlik kurulması düşünülen alana göre o alanda faaliyet gösteren merkezi yönetimin taşra teşkilatı veya merkezi yönetimin başkent teşkilatı tarafından reorganize edilmesi; bu yapıların kurumsallaşma sürecinde çok daha etkin ve verimli sonuçların alınmasını sağlayabilir. Bu nedenle hukuki düzlemde 1982 Anayasası’nın 127. maddesinde birlik kurulması ile ilgili izin hakkında; "Bakanlar Kurulu"na yapılan atıf kaldırılarak; "Mahallî idarelerin belirli kamu hizmetlerinin görülmesi amacı ile kendi aralarında birlik kurmaları, görevleri, yetkileri, maliye ve kolluk işleri ve merkezî idare ile karşılıklı bağ ve ilgileri kanunla düzenlenir”; şeklinde düzenlenmesi gerekmektedir.

Anayasa'da birlikler ile ilgili vesayet ilişkisini ve yetkisini desantralize etmeye imkan veren düzenlemenin yapılmasının ardından, 5355 Sayılı Mahalli İdare Birlikleri Kanunu’nda da birlik kurulmasında güdülen amaç ve alana göre, hangi merciinin yetkili olacağı hususu ayrıntılı şekilde yukarıdaki tabloda gösterildiği gibi ele alınabilir.

\section{Sonuç ve Değerlendirme}

Demokrasinin ve yerel kalkınmanın vazgeçilmez organizasyonları olan yerel yönetimlerin, yerel kamusal mal ve hizmetleri daha etkin, verimli, kaliteli ve sürekli bir şekilde temin edebilmesi, yine geleceğe yönelik stratejiler ile planlamalarını reel biçimde yapabilmesi, bu kuruluşların diğer kurum, kuruluş ve organizasyonlarla kuracakları ilişiklerin gücüne bağlıdır. Özellikle son dönemde siyasal alanda müzakereci ve oydaşmacı demokratik yaklaşımın yönetsel alandaki yansıması olan yönetişimci modelin Türkiye'de yerel yönetimler açısından hayata geçirilebilmesi; ancak bu kuruluşların yerel kamusal mal ve hizmetlerin sunumunda birlikteliklerinin güçlü bir şekilde kurumsallaşmasına bağlıdır.

1982 Anayasası ve 5355 Sayılı Mahalli İdare Birlikleri Kanunu Türkiye’de kırsal, kentsel ve bölgesel kalkınmanın lokomotifi olabilecek yerel yönetimlerin kendi aralarında birlik kurabilmeleri ile ilgili iznin ancak bakanlar kurulu tarafından verilebileceğini ifade etmiştir. Bu durum yerel yönetim birliklerinin kurulması sürecinde güçlü bir vesayet işletim süreci olarak yorumlanabilir. Her ne kadar birlikler yerine ölçek yaklaşımı üzerinden son dönemde yerel yönetimlere dönük yapılan reformlarda bu kuruluşların birbirleri ile birleştirilmesi ya da kapatılması yoluna gidilmiş olsa da; bu çözümlemenin bahsi geçen kuruluşların dayandığı değerlerden birisi olan demokratik yaklaşım ile çeliştiği aşikârdır. Fakat güçlü bir demokrasinin etkin ve verimli çalışan bir kurumsal yapı ile gerçekleştirilebileceği de unutulmamalıdır.

Bir ara formül olarak hem komün esaslı demokratik yerel yönetim kurgusunun sağlanması ve hem de yerel yönetimlerin ölçek üzerinden etkinliğinin temin edilebilmesi için bu kuruluşların kendi aralarında birlik şeklinde kurumsallaşabilmesinin önünün açılması gerekmektedir. $\mathrm{Bu}$ nedenle mevcut hukuki düzenlemelerin ortaya koyduğu güçlü vesayet yaklaşımı; subsidiarite ilkesi üzerinden desantralize edilmesi gerekmektedir.

Burada kırsal, kentsel ve bölgesel kalkınmanın ve demokratik gelişimin güçlü bir şekilde 
sağlanabilmesine dönük kurulması planlanan yerel yönetim birlikleri için vesayet ilişkisi bakımından yeni bir model önerisi getirilmiştir. Söz konusu yerel yönetimlerin birlik kurarken benimsediği şekil ve kapsadıkları alana göre izin verme yetkisi; "kaymakam", "vali", ve merkezi yönetim başkent teşkilatı arasında paylaştııılmışıtır. Böylelikle daha az bürokrasi ve hızlı ve doğru bilgi üzerinden yerel yönetimlerin birlikte hareket etme potansiyelinin güçlenmesi ve yerel kalkınmanın daha hızlı şekilde gerçekleştirilmesi sağlanabilir. 


\section{Kaynakça}

Avrupa Yerel Yönetimler Özerklik Şart1, http://www.tbb.gov.tr/mevzuat/kanunlar/Avrupa_Yerel_ Yonetimler_ozerklik_Sarti.pdf [Erişim Tarihi: 14.02.2016].

Boztepe, M. (2014) “Anayasa Mahkemesi Kararları Işı̆̆gnda Yerel Yönetimlerin Meclis Kararları Üzerinde Vesayet Denetimi”, Akademik Araştırmalar ve Çalışmalar Dergisi, Cilt: 6(10), Mayıs, 94-110.

Bilgin, M. (2002) "Yerel Yönetimlerin Bölgesel Kalkınmadaki Etkinliği: Göller Yöresi Uygulaması, Süleyman Demirel Üniversitesi İktisadi ve İdari Bilimler Fakültesi Dergisi, Cilt: 7(2): 313-330.

Çetin, M. (2007) “Yerel Ekonomik Kalkınma Yaklaşımı ve Uluslararası Organizasyonlar”, Yönetim ve Ekonomi Dergisi, Cilt: 14(1): 153-170.

Çukurçayır, M. A. (2013) Yerel Yönetimler Kuram Kurum ve Yeni Yaklaşımlar, (2. Baskı), Konya: Çizgi Kitabevi.

Eryılmaz, B. (2014) Kamu Yönetimi, Düşünceler Yapılar Fonksiyonlar Politikalar, Kocaeli: Umuttepe Yayınları.

"İdare-i Umumiye-i Vilayet Kanunu”, Kabul Tarihi: 1913, http://www.hukuki.net/kanun/11.01.text.asp, [Erişim Tarihi: 21.11.2014].

Kara, M. ve Görün M. (2008) "Kırsal Kalkınmada İl Özel İdarelerinin, Köylere Hizmet Götürme Birliklerinin ve İlçe Yönetimlerinin Rolü ve Bazı Uygulamalar”, Süleyman Demirel Üniversitesi İktisadi ve İdari Bilimler Fakültesi Dergisi, Cilt: 13(1): 411-433.

Keleş, R. (2012) Yerinden Yönetim ve Siyaset, (8. Basım), İstanbul: Cem Yayınevi.

Köseoğlu, M. (2010) "Yerel Yönetim Birliklerinin Sorunları ve Çözüm Önerileri”, Türk İdare Dergisi, Sayı: 468, Eylül, 85-102.

Resmi Gazete, “Belediye Kanunu”, Kanun No: 1580, Kabul Tarihi: 03.04.1930, Sayı: 1471, Tarih: 14.04.1930.

Resmi Gazete, “Belediye Kanunu”, Kanun No: 5393, Kabul Tarihi: 03.07.2005, Say1: 25874, Tarih: 13.07.2005.

Resmi Gazete, "Büyükşehir Belediyesi Sınırları İçerisinde İlçe Kurulması ve Bazı Kanunlarda Değişiklik Yapılması Hakkında Kanun”, Kanun No: 5747, Sayı: 26824 Mük., Tarih: 22.03.2008.

Resmi Gazete, “Köy Kanunu”, Kanun No: 442, Kabul Tarihi:18.03.1924, Say1: 68, Tarih: 07.04.1924.

Resmi Gazete, "Mahalli İdare Birlikleri Kanunu”, Kanun No:5355, Kabul Tarihi:26.05.2005, Sayı: 25842, Tarih: 11.06.2005.

Resmi Gazete, “1982 Anayasası”, Kabul Tarihi: 18.10.1982, Sayı: 17863 (Mükerrer), Tarih: 09.11.1982.

Resmi Gazete, "On Üç İlde Büyükşehir Belediyesi ve Yirmi Altı İlçe Kurulması ile Bazı Kanun ve Kanun Hükmünde Kararnamelerde Değişiklik Yapılmasına Dair Kanun”, Kabul Tarihi: 12.11.2012, Sayı: 28489, Tarih: 06.12.2012.

Parlak, B. (2014) “Avrupa Birliği Perspektifinden Merkezi Yönetim Yerel Yönetim İlişkileri”, TESAM Dergisi, Cilt: 1(1): 1-40.

Yerel Yönetim Birliklerinin Sayıları ve Ülke Bazında Fonksiyonlarına Göre Dağılımları http://www.migm. gov.tr/kurumlar/migm.gov.tr/YAYINLAR/FAAL\%C4\%B0YET\%20R APORARI/2014_Faaliyet_ Raporu.PDF) [Erişim Tarihi: 07.02.2016].

Zengin, G. (2011) "Yerel Yönetimler Aras İşbirliği Modelleri: Türkiye ve Avrupa Birliği Ülkelerindeki Yerel Yönetim Birlikleri Üzerine Bir İnceleme, Yalova Sosyal Bilimler Dergisi, Sayı: 2, Nisan Eylül, 86106. 